\title{
A política entre as nações: a luta pela guerra e pela paz ${ }^{*}$
}

ROGÉRIO DE SOUZA FARIAS*

A Coleção Clássicos Ipri vem conduzindo, desde 2001, a publicação de títulos internacionais inéditos ou esgotados da literatura especializada da área de relações internacionais no Brasil. Os volumes, que vêm acompanhados de prefácios redigidos por especialistas da área no Brasil, chegam ao mercado editorial em boa hora. A explosão de cursos de graduação na área, além do aumento da preocupação da própria sociedade com a chamada "agenda internacional" do país tem exigido uma compreensão muito mais sofisticada do sistema internacional e de seus impactos no plano doméstico.

A obra de Hans J. Morgenthau é a "jóia da coroa” da coleção, já que o volume é um divisor de águas na reflexão sobre a natureza e evolução da política internacional. Com efeito, a originalidade da obra está no seu objetivo de "descobrir e compreender as forças que determinam as relações políticas entre as naçôes" de forma sistemática, balizada por um arcabouço teórico que pretende ter um grande alcance explicativo da realidade internacional.

\footnotetext{
* MORGENTHAU, Hans J. A política entre as naçôes: a luta pela guerra e pela paz. Brasília: Editora Universidade de Brasília/ Instituto de Pesquisa de Relações Internacionais; São Paulo: Imprensa Oficial do Estado de São Paulo, 2003, 1152 p. ISBN: 85-7060-148-4 (Imprensa Oficial do Estado de São Paulo); 85-87480-27-8 (IPRI/FUNAG); 85-230-0763-6 (Ed. UnB).

** Bacharel em Relações Internacionais pela Universidade de Brasília e editor-assistente de RelNet - Rede Brasileira de Relações Internacionais.
} 
A obra não pode ser dissociada da vida de seu autor. Judeu nascido na Alemanha, Morgenthau passou os anos críticos da ascensão dos totalitarismos de direita peregrinando, como aluno e professor de Direito, no promontório do caos europeu. Sem dúvida, essa época marcou a sua percepção sobre as nefastas conseqüências da retórica da concepção liberal na política internacional. Não obstante, essas condições não eram estranhas à literatura, já que o movimento que ele chama de "depreciação da política do poder" no século XIX, E.H. Carr trata, quase dez anos antes, como uma conseqüência da concepção de "harmonia de interesses" na política internacional.

Radicado nos Estados Unidos, publicou a primeira edição do livro em 1948. O seu propósito era apresentar uma teoria sobre a política internacional, sendo essa balizada pela noção de que a política é governada por leis objetivas que tem as suas raízes na natureza humana. Aqui, a natureza humana exposta nos trabalhos de Hobbes e Maquiavel vão conjugar-se à influência que os escritos de Max Weber teve no pensamento de Morgenthau, para esse formular a categoria de poder que irá distinguir os fatos políticos dos não-políticos.

O realismo político será, portanto, a matriz na qual Morgenthau se esforçará em legar a autonomia disciplinar ao estudo da política internacional. Os impactos de sua visão do que constitui esse "realismo político" acompanhará para sempre as ponderações teóricas sobre a política internacional. Mas a resultante desse corolário tem efeitos bem mais profundos já que ao leitor de $A$ política entre as naçôes vai causar estranheza como a obra se vinculou de forma umbilical aos fundamentos da política exterior do governo americano.

Cabe observar que essa importância foi derivada, em grande medida, de duas ocorrências. Primeiro, vários de seus ex-alunos e leitores que se tornaram entusiastas de suas idéias ocuparam posiçóes-chave no aparelho governamental estadunidense. Segundo, em um período em que os Estados Unidos se alçavam como um dos pólos fundamentais da Guerra Fria, o seu trabalho de consultor do Departamento de Estado ajudou a construir o sustentáculo ideológico da política exterior americana no pós-guerra.

Apesar de essas contribuições serem derivadas, principalmente, da visão crua que o autor tem dos impactos da natureza humana na 
construção do sistema interestatal e de sua tese de que só o equilíbrio de poder é um instrumento relevante na manutenção da paz, uma qualificação deve ser feita. Como afirma Ronaldo Mota Sardenberg no prefácio da obra, "para Morgenthau a doutrina do poder não se esgota na simples e irrestrita aplicação de meios militares à vida internacional".

Dessa forma, Morgenthau, sempre em sua trajetória de vida, recusou identificar as aspirações morais de uma determinada nação com as leis morais que governam o universo, além de considerar a prudência como a virtude suprema na política. Essas teses do autor, a julgar sua própria oposição à Guerra do Vietnã, são especialmente relevantes em termos analíticos em uma época marcada pela retórica universalista e imprudência de alguns operadores da política externa estadunidense.

Por fim, ponderando as contribuiçôes do autor à hodierna teoria realista das relações internacionais, sistematizada principalmente por Kenneth Waltz e John Mearsheimer, podemos traçar paralelos e contrastes interessantes. Primeiro, a concepção de Morgenthau de política internacional é, sem dúvida alguma, derivada de uma concepção específica da natureza humana (a chamada "primeira imagem" na tese de Waltz). Mas a evolução da reflexão sobre a natureza das Relações Internacionais, a partir da década de 1970, tem conseguido um amplo grau de consenso na tese de que a natureza humana é uma categoria muito genérica e pouco explicativa para ser considerada uma causa da guerra e da paz. Portanto, esses novos teóricos vão focar a estrutura do sistema internacional, ou seja, sistematizar o realismo político em uma teoria sistêmica dedutiva e rigorosa de política internacional, criticando, assim, a abordagem de Morgenthau.

Contudo, ele estava ciente dessas críticas. $\mathrm{O}$ autor de $A$ política entre as naçôes sempre fez questão de definir a sua teoria como essencialmente histórica, criticando as abordagens sistêmicas como um exercício de formulação de "proposições abstratas com funções preditivas" que "falham tanto como guias de entendimento teórico como preceitos para ação”. Logo, apesar de Morgenthau não ser um historiador das relações internacionais, a sua visão sobre o papel das contingências históricas na política internacional ecoa um importante ensinamento para teóricos das relações internacionais desejosos de sacrificá-las no altar da parcimônia e do reducionismo. 